\title{
ПРИЙОМИ І МЕТОДИ РЕАБІЛІТАЦІЇ ДІТЕЙ 3 КОМПЛЕКСНИМИ ПОРУШЕННЯМИ ПСІХОФІ-ФІЗІОЛОГІЧНИХ РОЗВИТКУ. РЕАЛІЗАЦІЯ ІНДИВІДУАЛЬНОГО ПІДХОДУ
}

Оксана Михайленко, учитель К30 «Багатопрофільний навчально-реабілітаційний ресурсно-методичний центр корекційної роботи та інклюзивного навчання» ДОР»

Розглянуто проблеми організації індивідуального навчання дітей зі складними порушеннями психофізичного розвитку в умовах сучасної України. Наведено методи реалізації індивідуального підходу в навчанні учнів 3 комплексними порушеннями в умовах багатопросрільного навчально-реабілітаційного центру.

Ключові слова: комплексні порушення, учні з порушеннями слуху, корекційне навчання, індивідуальний підхід, альтернативні методи комунікації.

Оксана Михайленко, учитель КОУ «Многопрофильный учебно-реабилитационный ресурснометодческий центр коррекционной работы и инклюзивного обучения» ДОР»

Приемы и методы реабилитации детей с комплексными нарушениями психофизиологического развития. Реализация индивидуального подхода

Рассмотрено проблемы организации индивидуального обучения детей с множественными нарушениями психосиизиологического развития в Украине. Описано приемы реализации индивидуального подхода в условиях инклюзивных учебно-реабилитационных центров для детей с особыми образовательными потребностями.

Ключевые слова: комплексные нарушения, учащиеся с нарушениями слуха, коррекционное обучение, индивидуальный подход, альтернативные методы коммуникации

Oksana Mikhailenko, teacher MEI «Multidisciplinary educational-rehabilitation resource-methodical center of correctional work»

Methods for the rehabilitation of children with complex disorders of psycho-physiological development. The implementation of an individual approach

The problems of organizing individual education of children with multiple disorders of psycho-physiological development in Ukraine are considered. We describe the techniques for implementing an individual approach in an inclusive education and rehabilitation centers for children with special educational needs.

Keywords: complex infringements, students with hearing impairments, correctional training, individual approach, alternative methods of communication.

Aктуальність cmammi. Складні економічні умови, погіршення екологічної ситуації, техногенні перевантаження, важкі умови праці жінок, недосконалість чинної системи медичного і соціального забезпечення, високий рівень захворюваності батьків, погіршення якості продуктів харчування, зростання стресових ситуа() Михайленко 0., 2019 
цій у повсякденному житті спричиняють збільшення кількості дітей з різними видами захворювань. Так, за період 2003 - 2012 рр. чисельність дитячого населення знизилася на 19,02 \%. Водночас, загальна чисельність дітей-інвалідів щорічно збільшується на $0,5 \%$. Чисельність дітей-інвалідів станом на початок року сягнула показника 167059 осіб або 2, 0\% від усього дитячого населення країни [16].

За даними статистики, в Україні налічується понад півмільйона дітей із порушеннями слуху, понад 7,5 тис. дітей страждають розладами аутичного спектра. Щорічно народжується більше 400 дітей із синдромом Дауна та на даний момент в країні зареєстровано понад 15 тис. людей із цим захворюванням. Понад 20 тис. дітей із дитячим церебральним паралічем (ДЦП). Синдром дефіциту уваги і гіперактивності (СДУГ) спостерігається у 7\% українських дітей. При цьому офіційна статистика не відображає реальної картини і ці цифри на порядок вищі [5]. На 22,4\% збільшилася мережа навчальних закладів для дітей зі складними порушеннями розвитку (навчально-реабілітаційних центрів) та відповідно учнів у них: 2015/2016 н. р. - 58 закладів (6,4 тис. учнів), 2016/2017 н. р. 71 (7,9 тис. учнів) [16]. Навчання, виховання і реабілітація дітей зі складними порушеннями є маловивченою і складною проблемою спеціальної педагогіки. В учнів із комплексними порушеннями розвитку часто виникають труднощі в оволодінні навчальним матеріалом у строки передбачені програмами, маючи при цьому складнощі в процесі соціальної інтеграції [2].

Дослідники цього питання поділяють, залежно від структури порушення, дітей із поєднаними порушеннями на три основні групи:

- Діти, з двома вираженими психофізичними порушеннями.

- Діти, які мають одне виражене психофізичне порушення і супутне йому інше порушення, виражене в слабкому ступені.

Діти, які мають три або більше порушень виражених у різному ступені (множинні дефекти). До множинних дефектів, зокрема, можна віднести і поєднання в однієї дитини цілого ряду невеликих порушень, які мають негативний кумулятивний ефект, наприклад, при поєднанні невеликих порушень моторики, зору і слуху в дитини може мати місце виражене недорозвинення мови [6].

Вважають, що діти зі складними порушеннями розвитку це рідкісна, статистично малозначима категорія. Проте, згідно з даними досліджень і спостереженнями досвідчених дефектологів-практиків, такі діти становлять у середньому до 40 \% контингенту спеціальних освітніх установ. Практична потреба у вивченні цих дітей, визначенні їх освітніх потреб та у розробленні системи їх реабілітації надзвичайно важливі.

Аналіз останніх досліджень. Вагомий внесок у розробку шляхів і методів реабілітації дітей з комплексними порушеннями зробили В. Бондар, Л. Вавіна, Н. Засенко, В. Засенко, Т. Сак, С. Соботович, В. Синьов, В. Назарова, О. Хохліна, Т. Сжова, утім питання організації індивідуального підходу в навчанні дітей зі складними порушеннями психофізичного розвитку в умовах багатопрофільного навчально-реабілітаційного центру залишається недостатньо вивченим.

Метою cтатmi є висвітлення окремих корекційних прийомів роботи 3 учнями, що мають комплексні психофізичні порушення як на уроках, індивідуальних заняттях, так і в позаурочний час.

«ОСОБЛИВА ДИТИНА: навчання і виховання», № 2, 2019 
Особливим завданням спеціальних освітніх закладів є корекція розвитку дітей. Його розв'язання є не менш важливим і для інших типів закладів, у яких можуть навчатися діти з певними порушеннями розвитку. Компонентами спеціальної освіти є процеси навчання, виховання та корекція. При цьому корекція розглядається як основа навчально-виховної роботи в спеціальній школі: без цілеспрямованого подолання чи послаблення недоліків знижується ефективність навчання й виховання дітей: ускладнюється процес оволодіння необхідними для них знаннями, вміннями, навичками, становлення поведінки, особистості загалом. Водночас зауважимо, що виділити складові частини спеціальної освіти (навчання, виховання, корекція) можливо лише абстрагуванням функцій кожної з них для їх осмислення, організації, цілеспрямованої роботи. Якщо корекцію та навчання (і виховання) брати як відносно самостійні компоненти педагогічної системи, то відмінність між ними полягає в меті, особливостях педагогічного процесу, показниках ефективності.

Так, мета навчання - дати учням знання, уміння та навички, мета корекції виправляти порушення психічної і фізичної сфер розвитку, розвивати дитину загалом. Досягнення мети корекційного впливу забезпечують усі складові педагогічного процесу - організація, зміст, методика. Проте особливості корекційнорозвивального впливу визначаються не так закономірностями засвоєння навчального матеріалу, як його метою, визначеною відповідно до предмета корекції, його сутності, психологічних закономірностей впливу на нього. Саме від предмета корекції, тобто від того, що необхідно виправляти та розвивати в дитини, залежить постановка мети, пошук спеціальних шляхів організації педагогічного процесу, добір відповідних методичних засобів та змісту навчання, визначення показників його результативності [17].

Не можна залишати поза увагою суперечності між загальними для всього класу педагогічними вимогами (єдиний темп навчання, зміст програмового матеріалу) і різним рівнем розвитку пізнавальних можливостей учнів. За цих умов фронтальна робота з учнями може бути малоефективною. У будь-якому класі $є$ учні, яким важко засвоїти передбачені програмою предмета знання [2].

Отже, диференційоване навчання за групами залежно від рівня навчальних можливостей є однією з важливих умов реалізації принципу індивідуального підходу. Розробкою цього питання займалися І. Сременко, Л. Вавіна, Г. Мерсіянова, Н. Ф. Засенко та інші.

Важливого значення на початковому етапі знайомства з учнем та батьками та для вибору стратегії корекційного навчання та реабілітації учня з особливими освітніми потребами набуває вивчення анамнезу, діагнозу дитини, анкетні дані. Для цього в КЗО «Багатопрофільний навчально-реабілітаційний ресурснометодичнии щентр корекційної роботи та інклюзивного навчання» ДОР» на етапі знайомства з учнем ми вивчаємо витяг з протоколу обстеження, складаємо індивідуальну карту супроводу дитини, заводимо на кожного учня щоденники педагогічних спостережень та пропонуємо батькам таку форму взаємодії, як «Зошит взаємозв'язку з батьками» [14]. Зупинимось детальніше на кожному із них.

1. Індивідуальна соціально-педагогічна та медико-психологічна карта супроводу учня з особливими освітніми потребами 


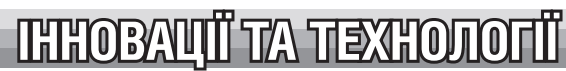

В індивідуальній карті супроводу зазначають: рік народження, домашня адреса, телефон батьків, дата початку здійснення супроводу (зарахування дитини в БНРЦ), закінчення здійснення супроводу, відомості про інвалідність, діагноз, витяг з протоколу ШПМПК [10]. Зразки такої картки та протоколу наведено в таблищі 1 та 2:

Таблиия 1

Індивідуальна соціально-педагогічна та медико-психологічна картка супроводу учня з особливими освітніми потребами

K30 «Багатопрофрільний навчально-реабілітаційний ресурсно-методичний центр корекційної роботи та інклюзивного навчання»ДОР»

ІНДИВІДУАЛЬНА СОЦІАЛЬНО-ПЕДАГОГІЧНА ТА МЕДИКО-ПСИХОЛОГІЧНА КАРТА СУПРОВОДУ УЧНЯ З ОСОБЛИВИМИ ПОТРЕБАМИ
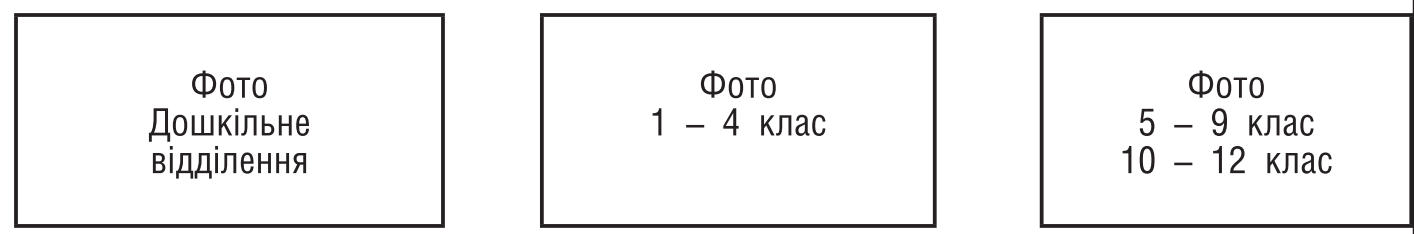

П.I.Б.

НОМЕР ОСОБОВОЇ СПРАВИ

Рік народження

Домашня адреса :

Телесрон: $\quad \underline{0689060806}$ Телесрон:

Дата початку здійснення супроводу:

Закінчено здійснення супроводу:

(Вказати, 3 яких причин)

ВИТЯГ 3 ПРОТОКОЛУ IPЦ

ДІАГНО3

Відомості про інвалідність:

\begin{tabular}{|l|l|}
\hline \multicolumn{1}{|c|}{ Дата } & \multicolumn{1}{c|}{ Висновок ІРЦ } \\
\hline $\begin{array}{l}\text { 30.03.2017 } \\
\text { (№ 15-с) }\end{array}$ & $\begin{array}{l}\text { Порушення слуху у формі двосторонньої сенсоневральної туговухості. } \\
\text { Дефіцитарний психічний розвиток у дитини 3 порушеннями слуху. } \\
\text { Особливості пізнавальних процесів та пізнавальної діяльності } \\
\\
\text { відповідають рівню затримки психічного розвитку. Працездатність } \\
\text { знижена, потребує активної допомоги, контролю. Навчальний досвід } \\
\text { переносить задовільно. Емоційно-вольова сфера незріла. Поведінка } \\
\text { впорядкована. Різко обмежений рівень мовленнєвого розвитку }\end{array}$ \\
\hline & \\
\hline
\end{tabular}


Зразок протоколу діагностичного засідання

\begin{tabular}{|c|c|c|}
\hline \multicolumn{3}{|c|}{ 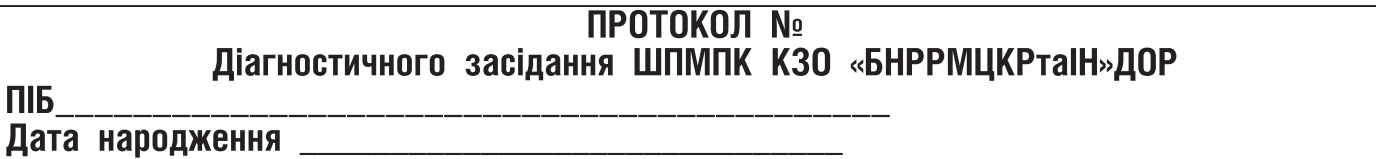 } \\
\hline № $\Pi / \Pi$ & Дитина має знати: & Дитина знає: \\
\hline \multicolumn{3}{|c|}{$\begin{array}{l}\text { Загальний розвиток } \\
\text { (зразок заповнення) }\end{array}$} \\
\hline & $\begin{array}{l}\text { Називає своє повне ім'я. (Прізвище, } \\
\text { ім'я, по батькові) }\end{array}$ & Називає самостійно \\
\hline & Називає скільки років? (Мені ... років) & Відповідає \\
\hline & $\begin{array}{l}\text { Називає дату свого народження. (число, } \\
\text { місяць, рік) }\end{array}$ & Називає число, місяць \\
\hline & $\begin{array}{l}\text { Називає ім'я та по батькові твоєї мами, } \\
\text { тата }\end{array}$ & Називає прізвище та ім'я батьків \\
\hline & Знає де і ким працюють мама, тато & Не може сказати \\
\hline
\end{tabular}

Важливим для здійснення корекційної мети є знання про стан здоров'я вихованця, які медичні працівники центру вносять у бланк таблиці 3.

Таблиия 3

Стан здоров'я вихованця

\begin{tabular}{|c|c|c|c|c|c|c|c|}
\hline \multicolumn{8}{|c|}{ 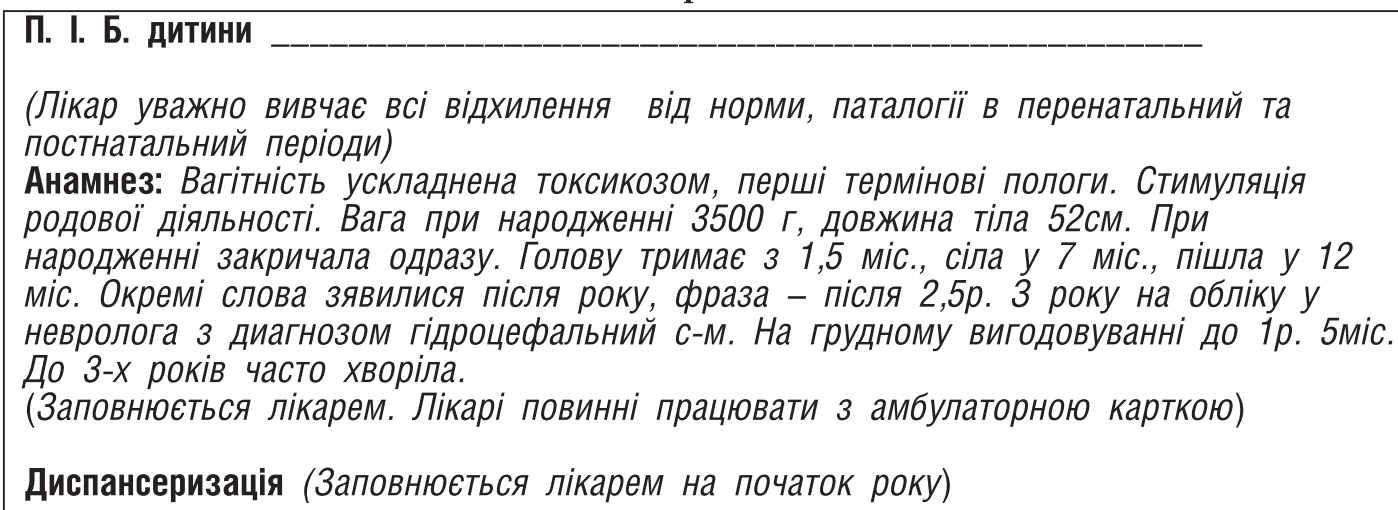 } \\
\hline Дата & $\begin{array}{c}\text { Соматичні } \\
\text { захворювання }\end{array}$ & $\begin{array}{l}\text { Стан } \\
\text { слуху }\end{array}$ & $3 i p$ & Хірург & Невропатолог & $\begin{array}{l}\text { Інші } \\
\text { спеціа- } \\
\text { лісти }\end{array}$ & $\begin{array}{c}\text { Фізкультурна } \\
\text { група }\end{array}$ \\
\hline 0-кл. & $\begin{array}{l}\text { Затримка } \\
\text { психологічного } \\
\text { розвитку } \\
\text { Гідроцифральний } \\
\text { синдром }\end{array}$ & здорова & $\begin{array}{l}\text { Vis } \\
\text { Dis } \\
1,0\end{array}$ & здорова & $\begin{array}{l}\text { Гідроцифальний } \\
\text { синдром }\end{array}$ & & Підготовча \\
\hline 1 & & & & & & & \\
\hline
\end{tabular}


Учитель ознайомлюється 3 анамнезом дитини i, на основі вищезазначеного, заводить на кожного учня щоденник педагогічних спостережень, до якого вносить короткі відомості про дитину, діагноз, анамнез та постійно записуємо свої спостереження за кожним учнем, його досягнення, успіхи, порушення поведінки, реакцію на ті чи інші подіі. Для поліпшення розвитку слухового сприймання учня з порушенням слуху, не залежно від супутніх діагнозів, ми рекомендуємо батькам вести «слуховий щоденник», у якому батьки вдома повинні відмічати новий звук, який почула дитина і реакцію на нього. Так для розвитку слухового сприймання важливими є слухання немовленнєвих звуків: музичних творів різних жанрів, звуки музичних інструментів (бажано зводити дитину в органний зал, на виступи симфонічних та джазових концертів тощо), під час прогулянки звертати увагу дитини на звуки, що нас оточують, а вдома на звуки «музичного будинку». 3 метою оптимізації корекційно-розвивальної роботи нами розроблено зошит взаємозв'язку з батьками, який заповнюється як батьками так і спеціалістами, що працюють з дитиною. Уся інформація, що надається, є конфіденційною та використовується педагогами (вихователями, учителем-логопедом, учителемдефектологом, практичним психологом) лише з метою збільшення ефективності корекційно-розвивального впливу. До зошита вносяться відомості про: оформлення наочного матеріалу з питань спеціальної освіти, анкетування та тестування батьків, індивідуальні консультації, батьківські збори, сумісна діяльність «діти батьки». У зошиті взаємозв'язку нами виділені такі розділи:

- анкетні дані (у розділі анкетних даних зазначається прізвище, ім'я дитини, дата народження, домашня адреса, склад сім'ї. Дані окремо заповнюються матір'ю та батьком: рівень освіти (середня, середня спеціальна, неповна чи повна вища), вік у момент народження дитини, стан здоров'я (соматичні, інфекційні, генетичні захворювання, шкідливі звички), місце і характер роботи, контактні телефони (домашній, робочий, мобільний). 3 метою порозуміння батькам надаються анкети українською та російською мовами на вибір батьків, короткий зразок наведено у таблиці 4:

\section{Зразок анкети для батьків}

Таблиця 4

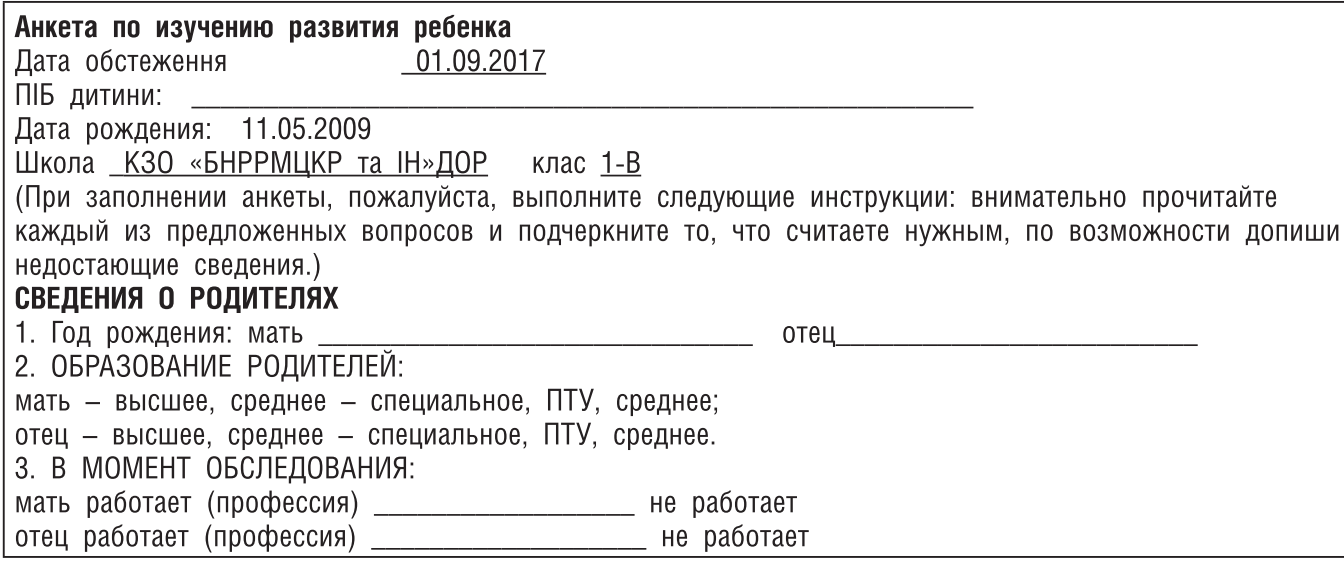




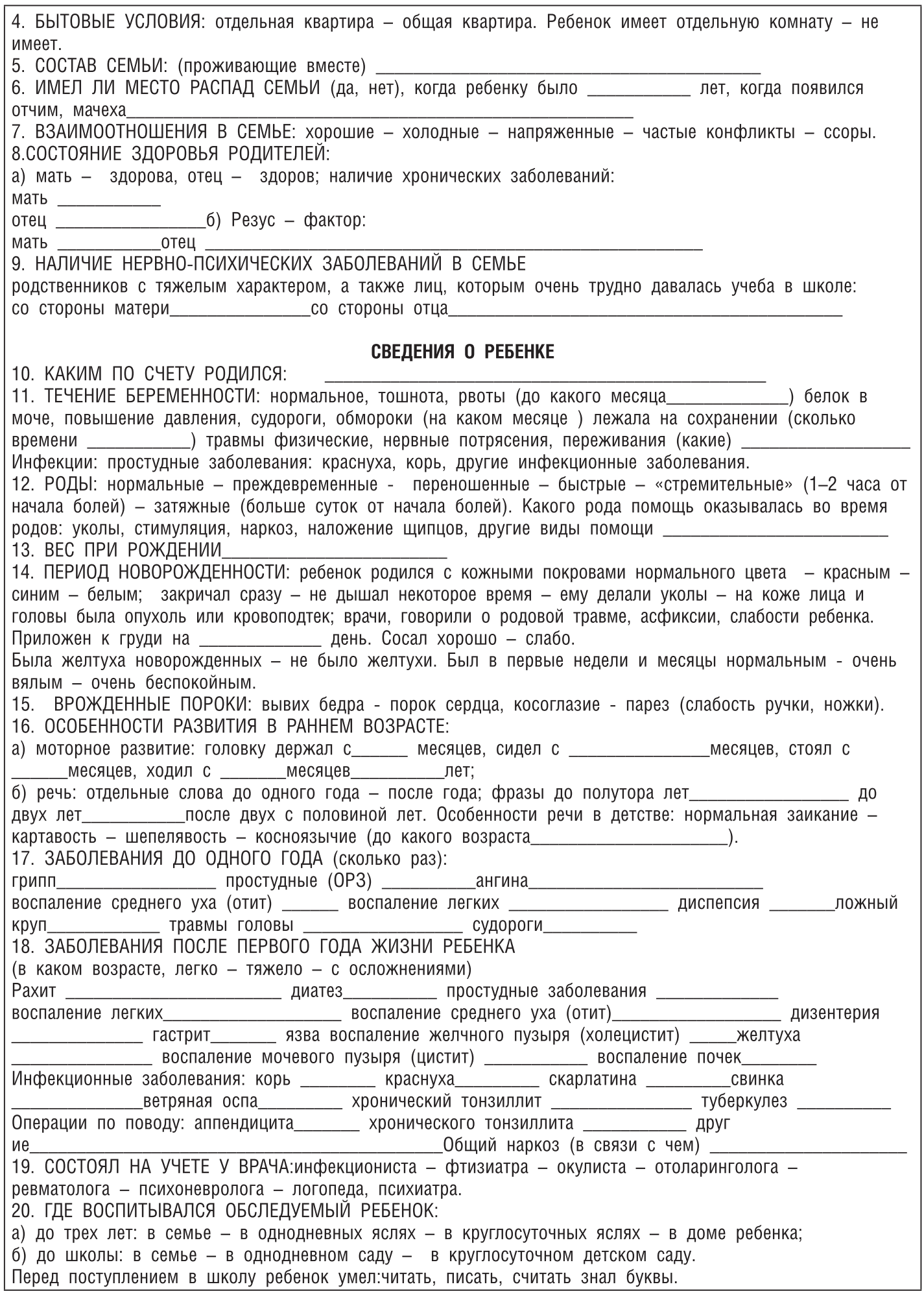




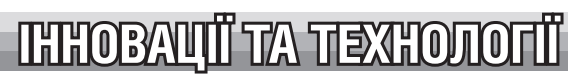

- психологічний мікроклімат у сім'ї (у розділі «Психологічний мікроклімат у сім'ї» розкриваються взаємостосунки дитини з членами родини (дружні, емоційно-напружені, конфлікти - 3 ким, наскільки часто; з ким найчастіше $з$ домашніх контактує), способи досягнення дорослим взаєморозуміння (яким чином, як часто, виховний вплив);

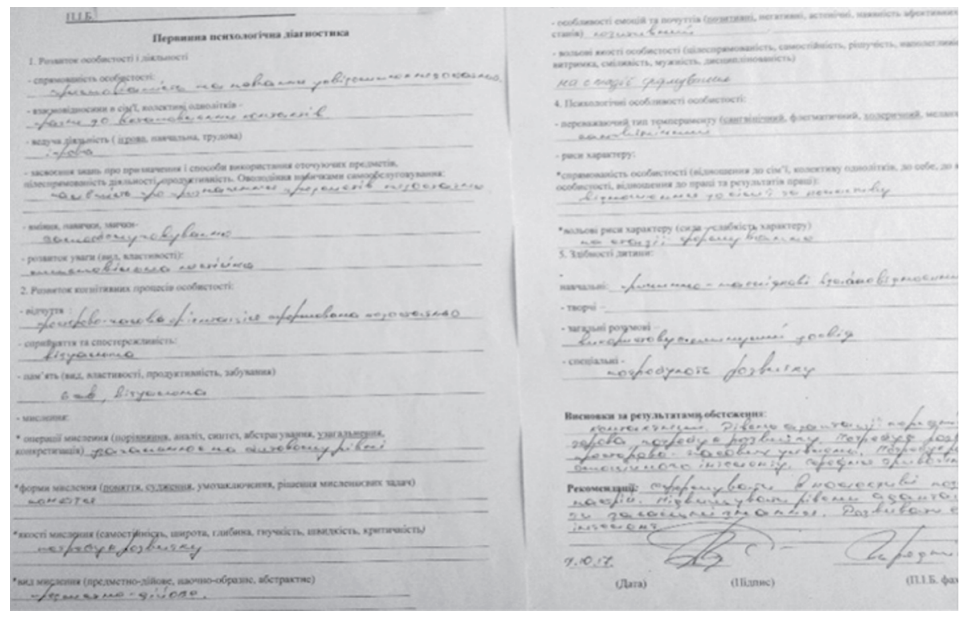

- соматичний стан дитини (у розділі «Соматичний стан дитини» зазначаються особливості слухових, зорових, моторних функцій школяра, схильність до захворювань (часто чи нечасто хворіє, чим саме, енурез, заїкання), вид диспансерного обліку (лікар, діагноз, дата), алергічні реакції (на продукти, препарати), харчування (наявність чи відсутність апетиту, ставлення до їжі, переваги, потреба в дієті);

- соціальний розвиток учня (у розділі «Соціальний розвиток дитини» описуються улюблені заняття, ігри та іграшки дошкільника, характер ігрової та суміс-

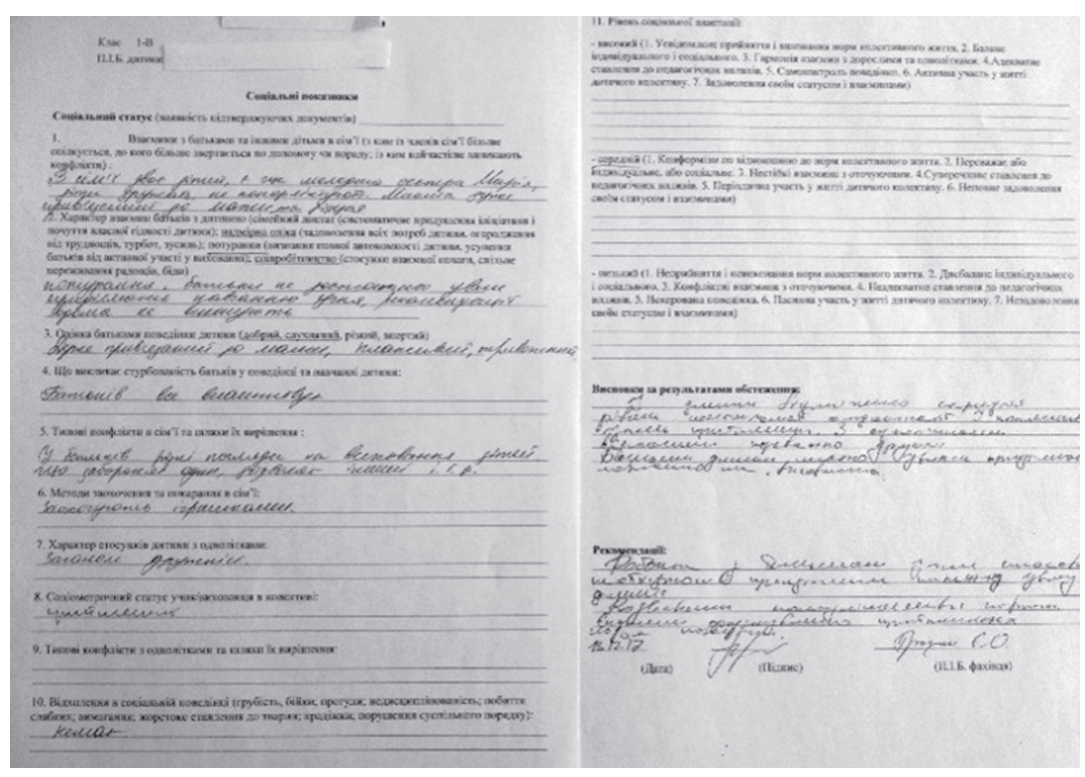

Мал. 1. Соціальний розвиток учня 
ної з дорослим діяльності (будівництво, ліплення, конструювання, малювання, настільні, рухливі ігри, доступні трудові доручення), проведення вільного часу (відпустка, вихідні, святкові дні, прогулянки). Зазначається рівень самостійності дитини (сформованість навичок самообслуговування, уміння гратися наодинці, можливість залишатися без батьків у дошкільному навчальному закладі чи упродовж нетривалого часу вдома), взаємостосунки з дорослими та ровесниками (уміння звернутися за допомогою, грати разом, ділитися іграшками, притримуватися певних правил), стиль контакту (переважно аудіальний, візуальний, кінестетичний, комбінований);

- мовленнєвий розвиток дитини (у розділі «Мовленнєвий розвиток» зазначається мовне (одно-, двомовне, мовний суржик) і мовленнєве (наявність, відсутність дефектів мовлення) середовище, у якому виховується дитина. Деталізується характер спілкування з дитиною (штучне, спонтанне, в яких видах діяльності, кількість часу, проведеного разом). Фіксується ступінь розуміння зверненого мовлення (на рівні інструкції чи тексту - розуміє, не розуміє, розуміє з труднощами), рівень сформованості самостійного мовлення дитини (звуконаслідування, окремі склади, слова, словосполучення, прості речення; використання в різних видах діяльності; переважання мовленнєвого чи немовленнєвого контакту, наявність чи відсутність потреби у спілкуванні). Як важлива складова мовленнєвого розвитку дітей окремо винесена робота 3 книжкою: зазначається відношення дитини до книжки (чи бережливо ставиться, чи любить розглядати ілюстрації, слухати текст; наскільки розуміє прочитане, чи запам'ятовує його зміст), час читання дитині (перед сном, під час ігор-занять або у вільний час), улюблені книжки (книжки-картинки, книжки-іграшки, вірші, казки, оповідання) [14].

- когнітивний розвиток учня (у розділі «Когнітивний розвиток дитини» корекційним педагогом заздалегідь добираються завдання відповідно віку та індивідуальним психофізичним особливостям дитини. Зазначається можливість маніпулювання дитиною розбірними іграшками (складання мотрійки, пірамідки, кубиків, вкладок) і використовуваний ним спосіб (самостійно, проб і помилок, за допомогою дорослого, за наслідуванням, пасивно), знання сенсорних еталонів (назви кольорів і відтінків, форм, величини), просторових понять, уміння рахувати, класифікувати предмети за сенсорними, родовидовими ознаками (виокремлення груп однорідних предметів, визначення зайвого предмета в групі), встановлюючи та пояснюючи причинно-наслідкові зв'язки, аргументуючи свій вибір. Звертається увага на наявність:

a) розвивальних ігор та іграшок удома (кількість; покупка, подарунок, сумісне виготовлення, улюблені, ігри та іграшки лише розважального характеру);

б) труднощів у навчанні (особливості сприймання, уваги, пам'яті, мислення, мовлення, поведінки; відсутність пізнавального інтересу, мотивації до ігор-занять);

в) розвивальної спрямованості ігор-занять (розвиток сприймання, уваги, пам'яті, мислення, мовлення; самостійно, підказка з боку спеціалістів, за допомогою спеціалістів, відсутність ігор-занять); 


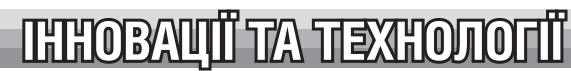

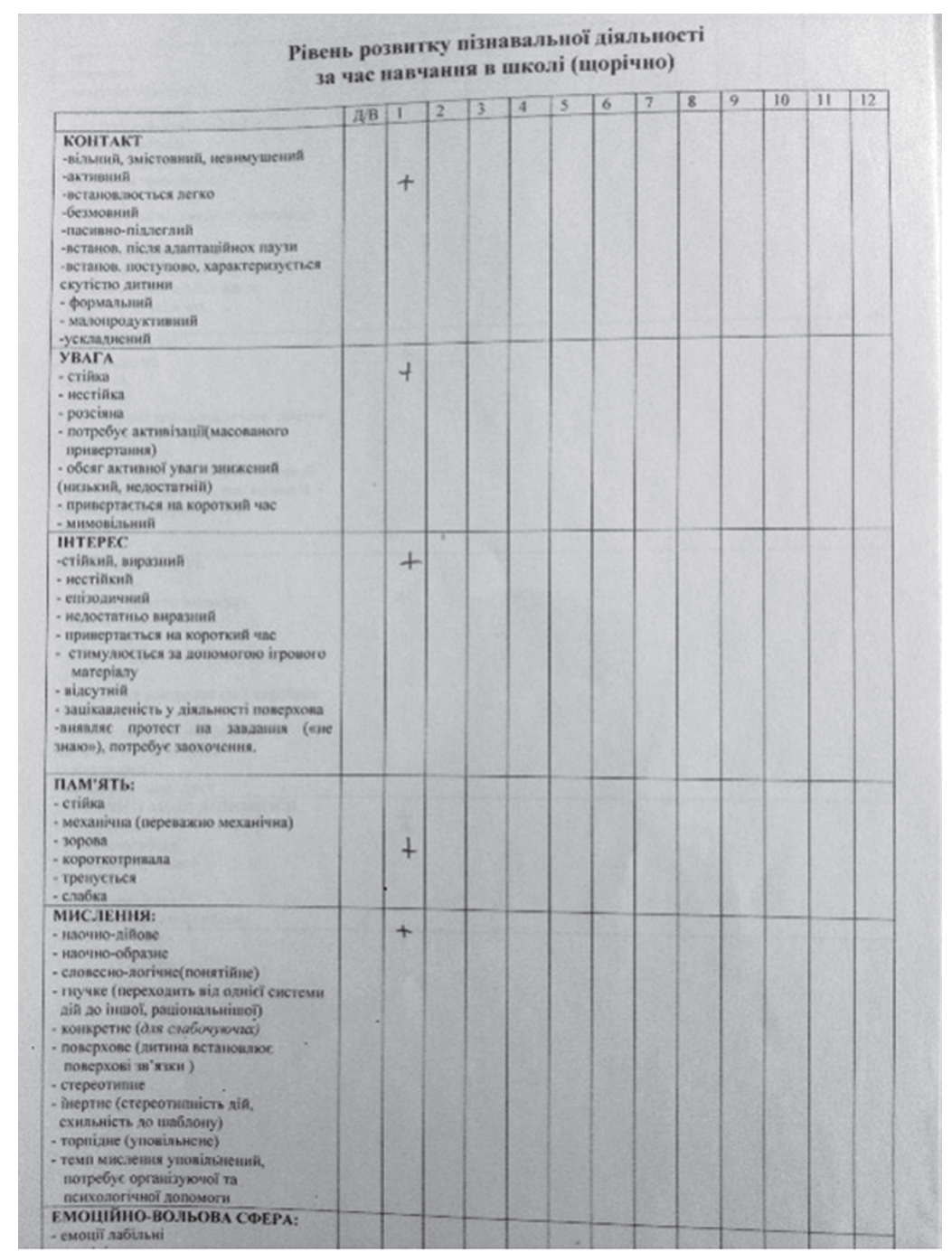

Мал. 2. Когнітивний розвиток дитини

- емоційно-вольова сфера (у розділі, присвяченому емоційно-вольовій сфері дошкільника, освітлюються питання самооцінки та самоідентифікації дитини (ставлення до себе та інших, фонд «можу», «хочу», «я сам», «хлопчик / дівчинка»; сформовані чи ні, знаходяться в зародковому стані), особливостей поведінки (адекватна, неадекватна; агресивність, збудливість, гіперактивність, негативізм, в'ялість, загальмованість, скромність), способи вираження емоцій (наявність зорового контакту під час спілкування, почуття гумору, вираження прохання, задоволення, незадоволення, протесту, відмови, вдячності, співчуття; уміє, не вміє, виражає непродуктивно) та виконання завдань (доводить розпочату справу до кінця, починає і кидає завдання, не береться за його виконання). Окремим підрозділом виступають переваги: що саме дитина любить чи не любить понад усе (одяг, іжа, іграшки, мультфільми, музика, ситуаціі), сильні і слабкі сторони дитини); 
- психолого-педагогічна підтримка сім’ї (у розділі «Психолого-педагогічна підтримка сім'ї» зазначаються ті соціальні інститути (служби), куди батьки зверталися з дитиною (час звернення, висновок, тривалість ігор-занять, результат), перелік консультацій спеціалістів (учитель-логопед, учитель-дефектолог, практичний психолог, отоларинголог, офтальмолог, невропатолог, психіатр, ортодонт, хірург; причина, час звернення, основні рекомендації, контакти (за необхідності);

- бесіди та консультації спещіалістів (у розділі «Бесіди і консультації спеціалістів БНРЦ» зазначається корисна інформація (що повинні знати спеціаліс-

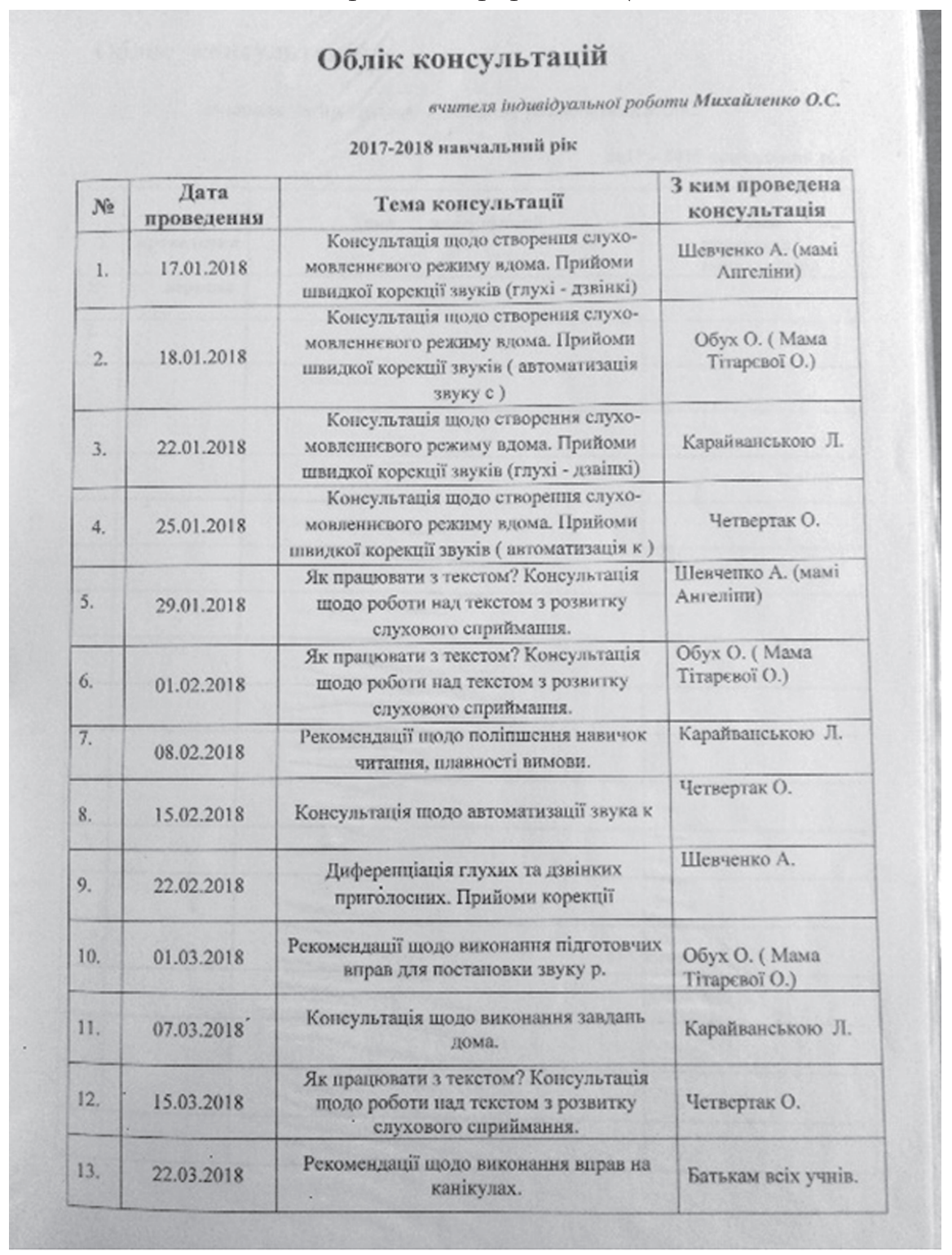

Мал. 3. Консультації для батьків 


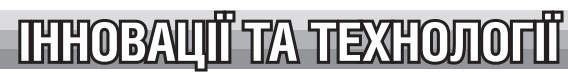

ти БНРЦ про дитину), конкретизуються запитання до спеціалістів (вихователів, учителя-логопеда, учителя-дефектолога, практичного психолога), у вигляді таблиці фіксуються зустрічі зі спеціалістами із зазначенням теми консультації та дати ii проведення). Так, зошит взаємозв'язку з батьками має велике значення як для самих батьків, адже дає змогу побачити цілісну картину сім'ї та виховання дитини, так і спеціалістів у корекційно-розвивальній роботі з дітьми з порушеннями мовленнєвого розвитку, адже дає можливість зекономити час для збору та аналізу необхідної інформації. Отже, ефективність корекційної роботи, гармонійний розвиток дитячої особистості багато в чому залежить від творчого співробітництва спеціалістів із батьками, від уміло налагоджених професійних та особистісних відносин між ними, чіткого та свідомого розуміння поставлених навчально-виховних і корекційно-розвивальних завдань [14, 13].

Також у КЗО «Багатопрофільний навчально-реабілітаційний ресурсно- методичний центр корекційної роботи та інклюзивного навчання» ДОР» обов'язково на кожного учня ми заводимо робочі папки для додаткових завдань та «зорові словники» зі словами необхідними для вивчення відповідно до лексичних тем, тем тижня та навчального матеріалу, який вивчається. Наводимо декілька малюнків:
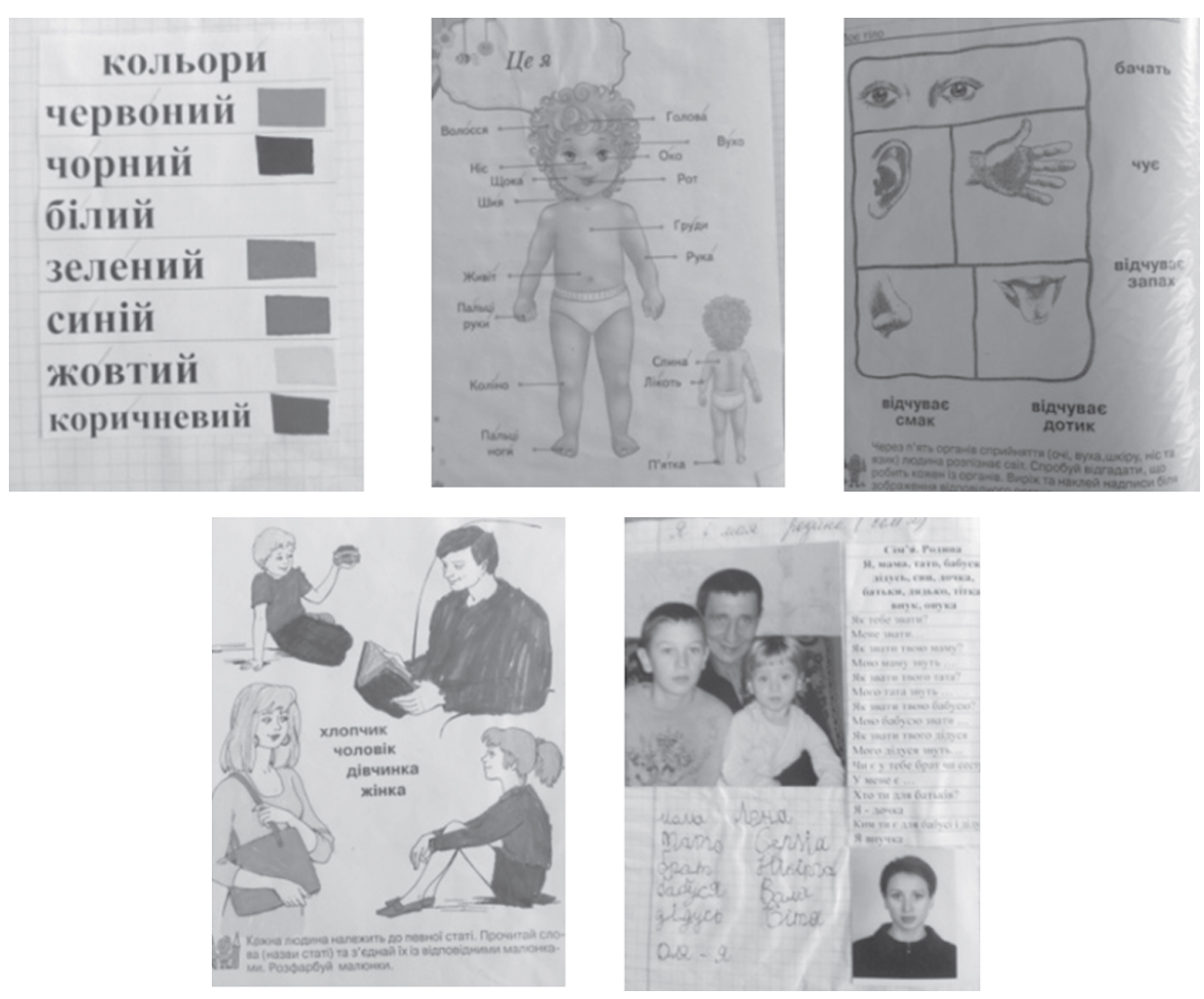

Мал. 4. Зоровий словник 
Познайомившись 3 учнем, його батьками, детально вивчивши анамнез, діагноз, спрогнозувавши можливі труднощі на основі спеціальних програм для навчання дітей із порушенням слуху, ми складаємо календарне планування та індивідуальну програму розвитку. У календарному плані ми прописуємо тему, очікувані результати, корекційні прийоми подолання певних труднощів як у вивченні навчального матеріалу, так і в поведінці дитини, особливостях сприймання нею інформації індивідуально для кожного учня.

Таблиия 5

Зразок календарного планування з української мови

Українсъка мова

(4 год на тиждень)

\begin{tabular}{|c|c|c|c|c|c|}
\hline № & иіст програмового матеріалу & Очікувані результати & & Дата & lpv \\
\hline & \multicolumn{5}{|c|}{ Звуки мовлення. Букви. Графічні навички письма } \\
\hline 5 & $\begin{array}{l}\text { Голосні звуки. Місце у слові. } \\
\text { Оформлення письмових робіт. } \\
\text { (Підруч.1, с.16 - } 17 \text { впр. } 32 \text { - } \\
\text { 35) } \\
\text { Наскрізна лінія: «Здоров’я } \boldsymbol{i} \\
\text { безпека: «У їдальніз»» }\end{array}$ & \multirow{4}{*}{$\begin{array}{l}\text { Учень: слухо-зоро- } \\
\text { вібраційно сприймає, } \\
\text { розрізняє та відтворює } \\
\text { вимову голосних звуків } \\
\text { визначає місце } \\
\text { голосного у слові } \\
\text { розрізняє наголошені і } \\
\text { ненаголошені голосні } \\
\text { слухо-зоро-вібраційно } \\
\text { сприймає, розрізняє } \\
\text { ( за можллиістю) } \\
\text { приголосні звуки, } \\
\text { порівнянює ї } \\
\text { артикуляцію та } \\
\text { звучаняя } \\
\text { розрізняє, називає } \\
\text { глухі і дзвінкі } \\
\text { приголосні, } \\
\text { визначає глухість- } \\
\text { дзвінкість приголосних } \\
\text { звуків у словах. } \\
\text { Розрізняє, називає } \\
\text { м'які й тверді } \\
\text { приголосні, визначає } \\
\text { м'якість-твердість } \\
\text { приголосних звуків у } \\
\text { словах }\end{array}$} & 1 & 11.09 & \multirow{4}{*}{$\begin{array}{l}\text { Подолання } \\
\text { артикуляційних } \\
\text { труднощів під час } \\
\text { вимови звуків. } \\
\text { Індивідуальна } \\
\text { робота з учнями: } \\
\text { Катя С. } \\
\text { Надання додаткових } \\
\text { вправ для розвитку } \\
\text { дрібної моторики } \\
\text { рук, вироблення } \\
\text { каліграфічч } \\
\text { ного почерку. } \\
\text { Оля Т. } \\
\text { розвиток дрібної } \\
\text { моторики } \\
\text { (пальчикові ігри, } \\
\text { ліплення, складання } \\
\text { лего, квілінг, тощо. } \\
\text { Індивідуальна } \\
\text { робота: } \\
\text { Микита С. } \\
\text { Надання } \\
\text { додаткових вправ } \\
\text { для подолання } \\
\text { дисграфії. } \\
\text { Зорові диктанти }\end{array}$} \\
\hline 6 & \begin{tabular}{|l|} 
Наголошені і ненаголошені \\
голосні. Ведення зошитів. \\
Виділення складової структури \\
i наголосу в словах. (підруч.1, \\
c.18 - 20, впр. $37-40$ )
\end{tabular} & & 1 & 12.09 & \\
\hline 7 & $\begin{array}{l}\text { сні звуки. Розпізнавання } \\
\text { кості мовних та } \\
\text { пеннєвих одиниць. } \\
\text { руч.1, с. } 22-26 \text {, впр. } \\
50)\end{array}$ & & 1 & 14.09 & \\
\hline 8 & \begin{tabular}{|l} 
Приголосні звуки. Слухо- \\
зоро-вібраційне сприймання, \\
порівняння артикуляції та \\
звучання, розрізнення (за \\
можливості) приголосних \\
звуків (підруч. 1, с. 26-27) \\
Наскрізна змістова лінія: \\
Екологічна безпека та сталий \\
розвиток: «Осінь»
\end{tabular} & & 1 & 9 & \\
\hline
\end{tabular}

У конспекті уроку ми відводимо окрему графу «Корекційна робота» де зазначаємо фронтальну корекційну роботу з класом відповідно до методики навчання осіб із порушеннями слуху, мети та завдань уроку, та індивідуальну 3 кожним учнем відповідно до супутнього діагнозу. У таблиці 6 наводимо зразок уроку з української мови: 


\begin{tabular}{|c|c|c|}
\hline $\begin{array}{c}\text { Дата } \\
18.09 .2018\end{array}$ & \multicolumn{2}{|l|}{ УКРАЇНСЬКА МОВА } \\
\hline Тема & \multicolumn{2}{|c|}{$\begin{array}{c}\text { Приголосні звуки. Слухо-зоро-вібраційне сприймання, порівняння артикуляції та } \\
\text { звучання, розрізнення (за можливості) приголосних звуків. Наскрізна змістова } \\
\text { лінія: Екологічна безпека та сталий розвиток: «Осінь». }\end{array}$} \\
\hline $\begin{array}{l}\text { Корекційна } \\
\text { мета }\end{array}$ & \multicolumn{2}{|c|}{$\begin{array}{c}\text { Повторити приголосні звуки. Розвивати мовлення учнів, критичне мислення, } \\
\text { пам'ять та увагу. Повторити алфавіт, написання вивчених словникових слів, } \\
\text { навички звуко-буквеного аналізу слів, письмо слів з апострофом та подвоєнням. } \\
\text { Вчити дітей розумінню необхідності вивчення мови для подальшого життя. } \\
\text { Виховувати любов до рідного слова, почуття радості від колективної праці. } \\
\text { Розвивати слухове сприймання, корегувати мовлення учнів. Корекція вимови. } \\
\text { Надання установок }\end{array}$} \\
\hline Обладнання & $\begin{array}{l}\text { Індивідуальні навчальні матриці, презентація, набір } \\
\text { кольорових кружечків для гри «Лото». } \\
\text { (Підруч.1, с. } 26-27) \text {, таблички для організації уроку }\end{array}$ & $\begin{array}{c}\text { Корекційна робота, } \\
\text { контроль, корекція } \\
\text { вимови та розвиток } \\
\text { слухового сприймання }\end{array}$ \\
\hline Хід уроку & 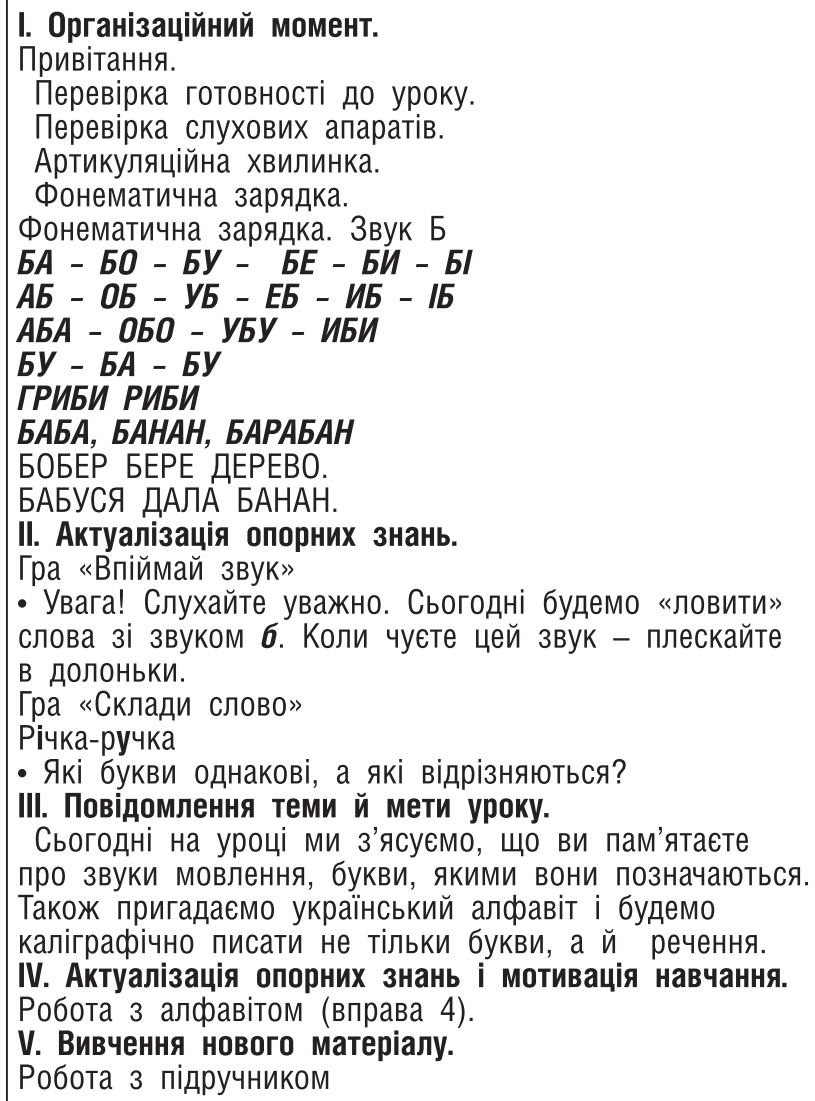 & $\begin{array}{l}\text { Розвиток слухового } \\
\text { сприймання } \\
\text { немовленнєвими звуками. } \\
\text { Фрази, що подаються на } \\
\text { слух: } \\
\text { Ти чуєш? } \\
\text { Який урок? відкрийте } \\
\text { зошити, відкрийте } \\
\text { підручники, закрийте } \\
\text { зошити. Корекційна } \\
\text { робота } \\
\text { Перевірка слухових } \\
\text { апаратів. } \\
\text { Артикуляційна зарядка. } \\
\text { Фонематична пауза. } \\
\text { Розчитування. } \\
\text { Індивідуальна робота } \\
\text { з учнями подолання } \\
\text { артикуляційних труднощів } \\
\text { під час вимови зуків, } \\
\text { автоматизація правильної } \\
\text { вимови звуків } \\
\text { Катя С. } \\
\text { Надання додаткових вправ } \\
\text { для розвитку дрібної } \\
\text { мотории рук, вироблення } \\
\text { каліграфрічного почерку. } \\
\text { Оля Т. } \\
\text { розвиток дрібної } \\
\text { моторики (пальчикові } \\
\text { ігри, ліплення, складання } \\
\text { лего, квілінг, тощо. }\end{array}$ \\
\hline
\end{tabular}

«ОСОБЛИВА ДИТИНА: навчання і виховання», № 2, 2019 


\begin{tabular}{|l|l|}
\hline a) вивчення правила на с. 27; & Микита с. \\
6)колективне виконання вправа 55. & Надання додаткових вправ \\
Vl. Закріплення вивченого на уроці. & для розвитку дрібної \\
- Самостійна робота учнів у зошиті. & моторики рук, вироблення \\
- Індивідуальна робота 3 окремими учнями. & каліграфічного почерку \\
VIl. Домашнє завдання. & Зорові диктанти \\
Пояснення домашнього завдання вправа 53 с. 26 & \\
VIII. Підбиття підсумків уроку. & \\
Рефлексія & \\
Що робили на уроці? & \\
Ми читали, писали, говорили. & \\
Яку тему ми сьогодні вивчали? & \\
Пи вивчали тему & \\
\hline
\end{tabular}

Отже, справа в колонці «Корекційна робота, контроль, корекція вимови та розвиток слухового сприймання» прописують види корекційної роботи, прийоми, методи як для всього класу так і індивідуально для кожного учня. Звертаємо увагу, що тема уроку складається як з назви твору, роботи над ним так із корекційної мети, яка ще раз прописується у відповідній графі і формується на основі програмових вимог, мети, завдань уроку та індивідуальних особливостей учнів з особливими освітніми потребами.

Особливим елементом корекційної спрямованості на першому уроці мовного циклу є виконання артикуляційної гімнастики, дихальних вправ та фонетичної зарядки. Для розвитку слухового сприймання на уроці використовуються елементи музичного супроводу та різноманітні «слухові ігри», а саме: різні варіації гри «Спіймай звук», «Хто покликав?», «Де ти почув звук?», «Тихо - голосно» тощо.

Висновок. У статті проаналізовано роботу вчителя КЗО «Багатопрофільний навчально-реабілітаційний ресурсно-методичний центр корекційної роботи та інклюзивного навчання» ДОР», починаючи зі знайомства з дитиною, вивчення діагнозу та анамнезу учня, розроблення індивідуальної програми розвитку, заведення щоденника педагогічних спостережень та індивідуальної карти супроводу, зошита взаємозв'язку з батьками. Також нами запропоновано деякі прийоми з реалізації індивідуального підходу до корекції, навчання та виховання учня з комплексними порушеннями в умовах багатопрофільного навчально-реабілітаційного центру.

\section{ЛITEPATУPA}

1. Альтернативні методи комунікації. - [Електронний ресурс] - Режим доступу до ресурcy: https://www.medel.com/support/rehabilitation/rehabilitation-downloads.

2. Антибура Ю. О. Індивідуальне навчання дітей зі складними порушеннями психофізичного розвитку як психолого-педагогічна проблема [Електронний ресурс] / Ю.О. Антибура // ВІСНИК ДНІПРОПЕТРОВСЬКОГО УНІВЕРСИТЕТУ ІМЕНІ АЛЬФРЕДА НОБЕЛЯ. Серія «ПЕДАГОГІКА І ПСИХОЛОГІЯ». Педагогічні науки, № 2 (10). - 2015. - Режим доступу до ресурсу: http://pedpsy.duan.edu.ua/images/stories/Files/2015-2/11.pdf.

3. Базовий компонент дошкільної освіти [Богуш А. М., Бєлєнька Г. В., Богініч О. Л. та ін.]; наук. керівник: А. М. Богуш, дійсний член НАПН України, проф., д. п. н. - К. : ТОВ «МЦФЕР Україна», 2012. - 26 с. 
4. Бондар B. Інтеграція навчання дітей-інвалідів і дітей з обмеженими фізичними та розумовими можливостями: за і проти //Діти з обмеженими фізичними та розумовими можливостями в системі корекційного навчання і виховання: Матер. Міжнар. наук.-практ. конф. 27 - 28 травня 1997 р. / Ред. кол.: В. І. Бондар та ін.- К., 1997.- С. $7-9$.

5. В Україні зростає кількість дітей з особливими потребами. - [Електронний ресурс] Режим доступу до ресурсу: https://www.obozrevatel.com/ukr/health/mamaclub/v-ukrainizrostae-kilkist-ditej-z-osoblivimi-potrebami.htm.

6. Діти зі складною структурою дефекту. - [Електронний ресурс] - Режим доступу до pecypcy: https://stud.com.ua/46688/pedagogika/diti_skladnoyu_strukturoyu_defektu.

7. Єжова Т.Є. Альтернативна комунікація як засіб соціальної реабілітації дітей з обмеженими можливостями життєдіяльності [ Електронний ресурс] - Режим доступу до ресурсу: http://ap.uu.edu.ua/article/102.

8. Жигорева, М. В. Дети с комплексными нарушениями в развитии: педагогическая помощь. - М.: Академия, 2006. - 240 с.

9. Засенко B., Колупаєва A. Шляхи інтеграції дітей з порушеннями слуху у суспільство // Громадянська освіта та соціалізація дітей з вадами слуху: 36. наук.-метод. матер.- К., 2002.C. $48-50$.

10. Інноваційні аспекти педагогічно-діагностичної діяльності закладів освіти по реабілітації дітей з вадами у розвитку [Текст] : метод. посіб. / Голов. упр. освіти і науки Дніпропетр. обл. держ. адмін., Дніпропетр. обл. ін-т післядиплом. пед. освіти, КЗО «Багатопроф. навч.-реабілітац. Центр Дніпропетр. обл. ради». - Д. : [б. и.], 2009 . Вип. 1 / упоряд. І. М. Родименко. - 2009. - 74 с.

11. Колупаєв А. А., Діти з особливими потребами в загальноосвітньому просторі: початкова ланка. / Колупаєва А. А., Таранченко О. М.../ - К.: «АТОПОЛ», 2010.

12. Леонтьев А. Н. Язык, речь, речевая деятельность [текст] / А. Н. Леонтьев. - М. : Просвещение, 2007. - 289 с.

13. Обухівська А. Г. Методичні та організаційні питання діагностико-консультативної діяльності психолого-медико-педагогічних консультацій / А. Г. Обухівська, Т. Д. Ілляшенко, Т. В. Жук та ін. - Київ : УНМЦ практичної психології і соціальної роботи, 2017. - 78 с.

14. Рібцун Ю. В. Дошкільнятко: корекційно-розвивальна та навчально-виховна робота 3 дітьми з фонетико-фонематичним недорозвитком мовлення : навч.-метод. посіб. / Ю. В. Рібцун. - К., 2014. -238 с.

15. Родименко І. М. Іноваційні технології інклюзії в навчально-виховному процесі у багатопрофільному навчально-реабілітаційному ресурсно-методичному центрі корекційної роботи та інклюзивного навчання / I. М. Родименко // Освіта осіб з особливими потребами: шляхи розбудови. - 2014. - Вип. 7. - С. 98-102. Режим доступу: http://nbuv.gov.ua/UJRN/ ooop_2014_7_16.

16. Статистичні дані/ Міністерство освіти і науки України. [Електронний ресурс]. Режим доступу: https://mon.gov.ua/ua/statistichni-dani

17. Хохліна О. П. Корекційно-розвивальна робота в спеціальних закладах освіти для дітей з порушеннями психофізичного розвитку: теоретичний аспект проблеми. - [Електронний ресурс] / О. П. Хохліна - Режим доступу до ресурсу: http://ap.uu.edu.ua/article/416.

18. Эльконин Д. Б. Психология игры [текст] / Д. Б. Эльконин. - М. : Владос, 1999. 359 с. 39. ЛОГО-АРТ [Електронний ресурс]. - Режим доступу: http://www.logoped.in.ua

\section{REFERENCES (TRANSLATED AND TRANSLITERATED)}

1. Alternatyvni metody komunikatsii [Elektronnyi resurs] - Rezhym dostupu do resursu: ttps://www.medel.com/support/rehabilitation/rehabilitation-downloads.

2. Antybura Yu.O. (2015). Indyvidualne navchannia ditei zi skladnymy porushenniamy psykhofizychnoho rozvytku yak psykholoho-pedahohichna problema [Elektronnyi resurs] /

«ОСОБЛИВА ДИТИНА: навчання і виховання», № 2, 2019 
Yu.O. Antybura // VISNYK DNIPROPETROVSKOHO UNIVERSYTETU IMENI ALFREDA NOBELIa. Seriia «PEDAHOHIKA I PSYKhOLOHIIa». Pedahohichni nauky, № 2 (10).Rezhym dostupu do resursu: http://pedpsy.duan.edu.ua/images/stories/Files/2015-2/11.pdf.

3. Bazovyi komponent doshkilnoi osvity [Bohush A. M., Bielienka H. V., Bohinich O. L. ta in.]; nauk. kerivnyk: A. M. Bohush, diisnyi chlen NAPN Ukrainy, prof., d. p. n. - K. : TOV «MTsFER Ukraina», 2012. - 26 s.

4. Bondar V. (1997). intehratsiia navchannia ditei-invalidiv i ditei z obmezhenymy fizychnymy ta rozumovymy mozhlyvostiamy: za i proty //Dity z obmezhenymy fizychnymy ta rozumovymy mozhlyvostiamy v systemi korektsiinoho navchannia i vykhovannia: Mater. Mizhnar. nauk.-prakt. konf. 27-28 travnia 1997 r. / Red. kol.: V. I. Bondar ta in.- K., S 7-9.

5. V Ukraini zrostaie kilkist ditei z osoblyvymy potrebamy. - [Elektronnyi resurs] Rezhym dostupu do resursu: https://www.obozrevatel.com/ukr/health/mamaclub/v-ukrainizrostae-kilkist-ditej-z-osoblivimi-potrebami.htm.

6. Dity zi skladnoiu strukturoiu defektu [Elektronnyi resurs] - Rezhym dostupu do resursu: https://stud.com.ua/46688/pedagogika/diti_skladnoyu_strukturoyu_defektu.

7. Yezhova T.Ye. Alternatyvna komunikatsiia yak zasib sotsialnoi reabilitatsii ditei z obmezhenymy mozhlyvostiamy zhyttiediialnosti [ Elektronnyi resurs] - Rezhym dostupu do resursu: http://ap.uu.edu.ua/article/102.

8. Zhyhoreva, M. V. Dety s kompleksnumy narushenyiamy v razvytyy: pedahohycheskaia pomoshch. - M.: Akademyia, 2006. $-240 \mathrm{~s}$.

9. Zasenko V., Kolupaieva A. Shliakhy intehratsii ditei z porushenniamy slukhu u suspilstvo // Hromadianska osvita ta sotsializatsiia ditei z vadamy slukhu: 36. nauk.-metod. mater.K., 2002.- S. 48-50.

10. Innovatsiini aspekty pedahohichno-diahnostychnoi diialnosti zakladiv osvity po reabilitatsii ditei z vadamy u rozvytku [Tekst] : metod. posib. / Holov. upr. osvity i nauky Dnipropetr. obl. derzh. admin., Dnipropetr. obl. in-t pisliadyplom. ped. osvity, KZO «Bahatoprof. navch.-reabilitats. Tsentr» Dnipropetr. obl. Rady». - D. : [b. y.], 2009 . Vyp. 1 / uporiad. I. M. Rodymenko. - 2009. - $74 \mathrm{~s}$.

11. Kolupaieva, A. A., Dity z osoblyvymy potrebamy v zahalnoosvitnomu prostori: pochatkova lanka. / Kolupaieva, A. A., Taranchenko, O. M.../ - K.: "ATOPOL", , 2010.

12. Leontev A. N. Yazik, rech, rechevaia deiatelnost [tekst] / A. N. Leontev. - M. : Prosveshchenye, 2007. - 289 s.

13. Obukhizska A. H. Metodychni ta orhanizatsini pytannia diahnostyko-konsultatyvnoi diialnosti psykholoho-medyko-pedahohichnykh konsultatsii / A. H. Obukhivska, T. D. Illiashenko, T. V. Zhuk ta in. - Kyiv : UNMTs praktychnoi psykholohii i sotsialnoi roboty, 2017. - $78 \mathrm{~s}$.

14. Ribtsun $Y u$. V. Doshkilniatko: korektsiino-rozvyvalna ta navchalno-vykhovna robota z ditmy z fonetyko-fonematychnym nedorozvytkom movlennia : navch.-metod. posib. / Yu. V. Ribtsun. - K., 2014. - 238 s.

15. Rodymenko I. M. Inovatsiini tekhnolohii inkliuzii v navchalno-vykhovnomu protsesi u bahatoprofilnomu navchalno-reabilitatsiinomu resursno-metodychnomu tsentri korektsiinoi roboty ta inkliuzyvnoho navchannia / I. M. Rodymenko // Osvita osib z osoblyvymy potrebamy: shliakhy rozbudovy. - 2014. - Vyp. 7. - S. 98-102. - Rezhym dostupu: http://nbuv.gov. ua/UJRN/ooop_2014_7_16.

16. Statystychni dani/ Ministerstvo osvity i nauky Ukrainy. [Elektronnyi resurs]. Rezhym dostupu: https://mon.gov.ua/ua/statistichni-dani

17. Khokhlina $O$. $P$. Korektsiino-rozvyvalna robota $\mathrm{v}$ spetsialnykh zakladakh osvity dlia ditei z porushenniamy psykhofizychnoho rozvytku: teoretychnyi aspekt problemy [Elektronnyi resurs] / O. P. Khokhlina - Rezhym dostupu do resursu: http://ap.uu.edu.ua/article/416.

18. Elkonyn D. B. Psykholohyia yhrы [tekst] / D. B. Elkonyn. - M. : Vlados, 1999. 359 s. 39. LOHO-ART [Elektronnyi resurs]. - Rezhym dostupu: http://www.logoped.in.ua. 